\title{
THE HEATS OF COMBUSTION OF METHYL AND ETHYL ALCOHOLS
}

\author{
By Frederick D. Rossini
}

\section{Abstract}

The heats of combustion of gaseous methyl and ethyl alcohols, at saturation pressure, from their mixture with air, under a constant total pressure of 1 atmosphere, were found to be $763.68 \pm 0.20$ for methyl alcohol at $25^{\circ} \mathrm{C}$. and $1,407.50 \pm$ 0.40 for ethyl alcohol at $32.50^{\circ} \mathrm{C}$., in international kilojoules per mole. By combining with these data the heats of vaporization recently determined by Fiock, Ginnings, and Holton and correcting the data for ethyl alcohol to $25^{\circ} \mathrm{C}$., the heats of combustion of the alcohols in the liquid state are computed to be $726.25 \pm 0.20$ for methyl alcohol and $1,366.31 \pm 0.40$ for ethyl alcohol, at $25^{\circ} \mathrm{C}$. and a constant pressure of 1 atmosphere, in international kilojoules per mole. With the factor $1.0004 / 4.185$ these values become, respectively, $173.61 \pm 0.05$ and $326.61 \pm 0.10 \mathrm{~kg}$-cal 15 per mole.

It was found that a rapid and accurate determination of the ratio of carbon to hydrogen in a volatile organic liquid can be made by saturating a stream of inert gas with the vapor of the liquid and then passing the mixture through hot copper oxide.

\section{CONTENTS}

I. Introduction

II. Method

III. Units, factors, atomic weights, etc

IV. Chemical procedure

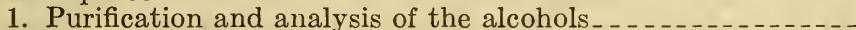

(a) Methyl alcohol

(b) Ethyl alcohol

2. Purity of the combustion reaction

3 . Determination of the amount of reaction

V. Calorimetric apparatus and procedure

VI. Calorimetric data on methyl alcohol

1. Correction experiments

2. Electrical energy experiments 127

3. Combustion experiments

4. Results of the present work

5. Data of previous investigators. 130

VII. Calorimetric data on ethyl alcohol 132

1. Correction experiments

2. Electrical energy experiments

3. Combustion experiments

4. Results of the present work

5. Data of previous investigators

VIII. Conclusion.

IX. Acknowledgments. 138

X. Bibliography

\section{INTRODUCTION}

With the development of the third law of thermodynamics, by means of which values of the entropy of pure substances can be calculated from data on their heat capacities down to low tem- 
peratures, ${ }^{1}$ it has become possible to compute the free energy of formation of many organic compounds. For such a calculation there are required values for $\Delta S_{T}^{\circ}$, the entropy of formation, and $\Delta H^{\circ}{ }_{T}$, the heat of formation of the compound. The former is obtained from values of $S^{\circ}$, the entropy, at $T^{\circ} \mathrm{K}$, of the compound and of the elements from which it is formed; and the latter is computed from the heat of combustion of the compound (and the heats of formation of water and carbon dioxide) at $T^{\circ} \mathrm{K}$.

Because the heat of formation of an organic compound is usually only a small fraction of its heat of combustion, it is necessary that the heat of combustion be known with considerable accuracy in order that the uncertainty in the value of the heat of formation shall not contribute an error to the calculated free energy greater than that contributed by the uncertainty in the entropy values.

The present work is an effort to establish with the necessary accuracy the heats of combustion of methyl and ethyl alcohols, because the existing data are markedly discordant. In the case of methyl alcohol, the high and low values reported by competent investigators differ by some $1 \frac{1}{2}$ per cent. ${ }^{2}$ A similar spread of the data exists in the case of ethyl alcohol, where the results of the latest two investigations differ by one-half per cent. ${ }^{3}$

\section{METHOD}

In the present investigation, alcohol vapor was burned at constant pressure in a reaction vessel in the calorimeter. The selection of gaseous rather than liquid alcohol for combustion was made because an accurate apparatus for the combustion of gases was already assembled (2), ${ }^{4}$ and because the heats of vaporization of methyl and ethyl alcohols were being determined in another division of this bureau (3). The alcohol was carried as a vapor into the reaction vessel in the calorimeter by a stream of purified air. There the combustible mixture, ignited by means of a spark, burned quietly in a flame at the burner tip. Most of the water formed was condensed to liquid in the reaction vessel, while all of the carbon dioxide and some water vapor were carried out of the calorimeter by the excess gas.

The thermal effect produced in the calorimeter system by the heat liberated in the combustion was duplicated with electrical energy under identical calorimetric conditions.

\section{UNITS, FACTORS, ATOMIC WEIGHTS, ETC.}

The fundamental unit of energy employed in the present work, and the factors used to convert this unit into other commonly used units of energy, are given in previous papers (2).

The atomic weights of carbon, hydrogen, and oxygen are taken as $12.000,1.0078$, and 16.0000 , respectively (4). One mole of $\mathrm{CO}_{2}$ $(44.000 \mathrm{~g})$ is taken as equivalent to 1 mole of $\mathrm{CH}_{3} \mathrm{OH}$, or to one-half mole of $\mathrm{C}_{2} \mathrm{H}_{5} \mathrm{OH}$.

\footnotetext{
1 For qualifications and restrictions upon the application of the third law of thermodynamics in computing entropy values, see (1).

2 These data are discussed at length on p. 129.

8 These data are discussed in detail on p. 134 .

1 The figures in parentheses here and throughout the text relate to the reference numbers in the bibliog. raphy given at the end of this paper.
} 
The heat capacities of methyl alcohol vapor at $25^{\circ} \mathrm{C}$. and of ethyl alcohol vapor at $32.5^{\circ} \mathrm{C}$. are taken as 47 and 68 joules per mole per degree, respectively. ${ }^{5}$

The heat capacities of liquid methyl and ethyl alcohols, and their heats of vaporization, are taken from the data of Fiock, Ginnings, and Holton (3).

All other auxiliary data are the same as previously used by the present author (2).

\section{CHEMICAL PROCEDURE}

\section{PURIFICATION AND ANALYSIS OF THE ALCOHOLS}

\section{(a) METHYL ALCOHOL}

The methyl alcohol used in the present investigation was prepared from a sample of the best synthetic material available, by distillation in a 30 -plate bubbling-cap still (6). Only the middle portion of the distillate was used. As reported in another investigation on the thermal properties of this methyl alcohol (3), the purified sample had a density $\left(d_{4}^{20}=0.79133\right)$ practically identical with the "best" value $\left(d_{4}^{20}=0.79134\right)$ given in the International Critical Tables (7).

Because of the variable amounts of methyl alcohol vapor (1 to 2 $\mathrm{mg}$ ) which came through unburned during the sparking period, it was not possible to make an accurate determination of the ratio of carbon to hydrogen in the methyl alcohol by combustion in the calorimetric reaction vessel. ${ }^{6}$ Accordingly, a series of combustion analyses to determine the ratio of carbon to hydrogen in this methyl alcohol was made by passing the alcohol vapor, carried by a stream of helium gas, through copper oxide at $600^{\circ}$ to $700^{\circ} \mathrm{C}$., and absorbing the water and carbon dioxide formed in "dehydrite" $\left(\mathrm{Mg}\left(\mathrm{ClO}_{4}\right)_{2} \cdot 3 \mathrm{H}_{2} \mathrm{O}\right)$ and "ascarite" (a sodium hydroxide-asbestos mixture), respectively.

The complete train for these experiments consisted of the following: (a) A cylinder of helium gas; (b) a preheating furnace containing copper oxide at $700^{\circ}$ to $800^{\circ}$ C.; (c) an absorbing tube containing "ascarite"; $(d)$ a tube containing "dehydrite"; $(e)$ a tube containing phosphorus pentoxide; $(f)$ a vessel for saturating the helium gas with methyl alcohol vapor (this saturator was arranged with a by-pass to permit flow of the helium gas without carrying any alcohol); $(g)$ a quartz tube, 30 inches long, filled with copper oxide kept at $600^{\circ}$ to $700^{\circ} \mathrm{C}$.; $(h)$ a condensing chamber for collecting, temporarily, the water which condensed to liquid during the combustion period; ; ${ }^{7}$ (i) a $U$ tube containing "dehydrite" and phosphorus pentoxide; $(j)$ a second U tube containing "ascarite" and phosphorus pentoxide; and $(k)$ a guard tube containing, in order, phosphorus pentoxide, "dehydrite," and "ascarite."

In carrying out an analysis with this apparatus the entire system was first flushed out and filled with helium; the weighed U-tube absorbers, filled with helium, were put in place, and a blank determination was made with helium flowing through the train. In the com bustion period the helium was passed through at such a rate that $1 \mathrm{~g}$ of methyl alcohol was carried into the reaction region in about 30

\footnotetext{
3 Extrapolated from the data given in (5).

- The details of such analyses are given in the following part of this section, under ethyl alcohol

'The combustion was carried on at such a rate that the amount of water formed was greatly in excess of that which was necessary to saturate the stream of gas at room temperature.
} 
minutes. When a sufficient amount of alcohol had been burned, as determined by inspection of the amount of carbon dioxide absorbed in the "ascarite," the helium was by-passed around the liquid methyl alcohol, and the flow of helium was continued until all of the water had been transferred from the condensing chamber to the first $U$ tube, which contained "dehydrite." The method of weighing the absorbing tubes and correcting the observed increases in weight to vacuum in order to obtain the true masses of water and of carbon dioxide has already been described (2). Tests showed the absence of carbon monoxide in the products of combustion. ${ }^{8}$ The amounts of carbon dioxide collected in the six experiments varied from 0.5 to $3.5 \mathrm{~g}$.

TABLE 1.-Ratio of carbon to hydrogen in the methyl alcohol

\begin{tabular}{|c|c|c|c|c|}
\hline Experiment & $\begin{array}{c}\text { Mass of } \\
\mathrm{H}_{2} \mathrm{O}\end{array}$ & $\begin{array}{l}\text { Mass of } \\
\mathrm{CO}_{2}\end{array}$ & $\frac{2\left(\text { moles } \mathrm{CO}_{2}\right)}{\left(\text { moles } \mathrm{H}_{2} \mathrm{O}\right)}$ & $\begin{array}{l}\text { Deviation } \\
\text { from } \\
\text { mean }\end{array}$ \\
\hline 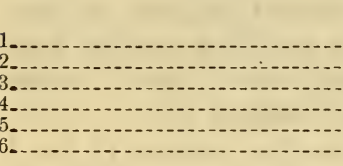 & $\begin{array}{l}g \\
2.13165 \\
1.24489 \\
1.76721 \\
2.37995 \\
2.83170 \\
.43463\end{array}$ & $\begin{array}{r}g \\
2.60363 \\
1.51875 \\
2.15803 \\
2.90600 \\
3.46040 \\
.53065\end{array}$ & $\begin{array}{r}1.00021 \\
.99904 \\
.99999 \\
.99989 \\
1.00070 \\
.99980\end{array}$ & $\begin{array}{r}0.0002 \\
-.00090 \\
.00005 \\
-.0000 \\
.0007 \\
-.0001\end{array}$ \\
\hline Mean 1-- & & - & .99994 & \pm .00030 \\
\hline
\end{tabular}

1 Omitting the results of experiments 2 and 5 gives $0.99997 \pm 0.00013$.

The results of these analyses, given in Table 1, show that the ratio of carbon to hydrogen in this sample of methyl alcohol was that required by the formula $\mathrm{CH}_{3} \mathrm{OH}$, within the limits of precision of the determination $( \pm 0.03$ per cent).

(b) ETHYL ALOCHOL

The purification of the ethyl alcohol has already been described (3). The sample used in the present investigation was from the middle portion of the distillate from the 30-plate column. From a measurement of the density of this sample $\left(d_{4}^{20}=0.78946\right)$ and the data given by Osborne, McKelvey, and Bearce (8) for the densities of pure ethyl alcohol and mixtures of it with water, Fiock, Ginnings, and Holton (3) computed the amount of water in the alcohol to be 0.038 per cent by weight.

In order to check this value, the data from the combustion experiments in the calorimetric reaction vessel were used to compute the ratio of carbon to hydrogen in this sample of ethyl alcohol. Because, under the conditions of the experiments, ethyl alcohol ignited more quickly than did methyl alcohol, the amounts of ethyl alcohol which came through unburned during the sparking period were small (about $0.6 \mathrm{mg}$ ) and practically constant. In this connection experiments were made which showed that no alcohol vapor passed through an absorption tube containing "dehydrite" and phosphorus pentoxide.

From the combustion experiments in the calorimetric reaction vessel the following data were available: $(a)$ The increase in weight of the carbon dioxide absorber, $(b)$ the increase in weight of the water absorber, and $(c)$ the mass of alcohol $(0.00058 \mathrm{~g})$ that was unburned

These tests were the same as those described in an earlier paper (2). 
during the sparking period (five seconds). By subtracting $0.00058 \mathrm{~g}$ from the increase in weight of the water absorber, and converting the weights of water and carbon dioxide to vacuum, values of the ratio $\frac{2}{3} \frac{\left(\text { moles } \mathrm{H}_{2} \mathrm{O}\right)}{\left(\text { moles } \mathrm{CO}_{2}\right)}$ were obtained from seven experiments. These data are given in Table 2. From the average value of 1.00037 for this ratio, the amount of water in the alcohol is computed to be 0.043 per cent by weight. This agrees, within the experimental error, with the value obtained from the density measurements.

TABLE 2.-Ratio of carbon to hydrogen in the ethyl alcohol

\begin{tabular}{|c|c|c|c|c|}
\hline Experiment & $\begin{array}{c}\text { Mass }{ }^{1} \text { of } \\
\mathrm{H}_{2} \mathrm{O}\end{array}$ & $\underset{\mathrm{CO}_{2}}{\text { Mass of }}$ & $\frac{2\left(\text { moles } \mathrm{H}_{2} \mathrm{O}\right)}{3\left(\text { moles } \mathrm{CO}_{2}\right)}$ & $\begin{array}{l}\text { Deviation } \\
\text { from mean }\end{array}$ \\
\hline $\begin{array}{l}\mathrm{X} \\
\mathrm{A} \\
\mathrm{A} \\
\mathrm{B} \\
\mathrm{C} \\
\mathrm{D} \\
\mathrm{D} \\
\mathrm{E} \\
\mathrm{F}\end{array}$ & $\begin{array}{l}g \\
1.64219 \\
1.69878 \\
1.72781 \\
1.68556 \\
1.72177 \\
1.69205 \\
1.67569\end{array}$ & $\begin{array}{c}g \\
2.67210 \\
2.76374 \\
2.81263 \\
2.74384 \\
2.80318 \\
2.75433 \\
2.72742\end{array}$ & $\begin{array}{l}1.00065 \\
1.00081 \\
1.00022 \\
1.00023 \\
1.00009 \\
1.00025 \\
1.00035\end{array}$ & $\begin{array}{r}0.00028 \\
.00004 \\
-.00015 \\
-.00014 \\
-.00026 \\
-.00012 \\
-.00002\end{array}$ \\
\hline Mean ${ }^{2} \ldots \ldots$ & 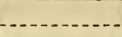 & ..... & 1.00037 & \pm .00020 \\
\hline
\end{tabular}

1 The actual increase in mass of the absorber for water was decreased by $0.00058 \mathrm{~g}$ to give the mass of $\mathrm{H}_{2} \mathrm{O}$. This is explained in the text, p. 122.

2 Omitting the results of experiment A gives $1.00030 \pm 0.00015$; and omitting the results of experiments $\mathrm{A}$ and $\mathrm{X}$ gives $1.00023 \pm 0.00006$.

\section{PURITY OF THE COMBUSTION REACTION}

The air used to carry the alcohol vapor into the reaction vessel in the calorimeter was freed from carbon dioxide and water vapor by preliminary passage through "ascarite," "dehydrite," and phosphorus pentoxide. There was no cumbustible material in the air because, when it was passed through a tube containing palladinized asbestos at $500^{\circ} \mathrm{C}$., no carbon dioxide was detected in the exit gas. The oxygen used to supply the "atmosphere" for these combustions was the same as that used in the previous investigations and was similarly purified (2).

In order to determine whether the process of bubbling air through the alcohol caused any oxidation, oxygen was passed through a sample of pure alcohol at $40^{\circ} \mathrm{C}$., and the vapors were condensed to liquid at $0^{\circ} \mathrm{C}$. Tests of the initial liquid and of the distillate showed the presence of only a trace ( 1 in 100,000 ) of aldehyde, both in the case of methyl alcohol and of ethyl alcohol. ${ }^{9}$

Examination of the gaseous products of the combustion of methyl alcohol showed the presence of a negligible amount of formaldehyde (1 mole per 800,000 moles of alcohol), and of nitrogen oxides ${ }^{10}$ (1 mole per 40,000 to 60,000 moles of alcohol). No carbon monoxide was found in tests which would have detected 1 mole per 30,000 moles of methyl alcohol.

In the case of ethyl alcohol, examination of the gaseous products of combustion showed the presence of a negligible amount of nitrogen oxides ( 1 mole per 20,000 to 30,000 moles of alcohol) and a trace of carbon monoxide (1 mole per 20,000 moles of alcohol). In the liquid 
water produced in the combustion of ethyl alcohol the amount of nitric acid formed from nitrogen oxides and water was about 1 mole per 40,000 moles of alcohol, and the amount of acetic acid, if any, formed from incomplete combustion of the alcohol, was not more than 1 mole per 60,000 moles of ethyl alcohol. ${ }^{11}$

The heat effects accompanying these side reactions are negligible. Their effect upon the measured heat value is in some cases positive and in others negative. In the worst case the effect is about 0.005 per cent.

\section{DETERMINATION OF THE AMOUNT OF REACTION}

In the calorimetric combustion experiments the amount of reaction was determined from the mass of carbon dioxide formed. The procedure employed in handling and manipulating the absorbing tubes, and the method of calculating the weights to vacuum have already been described (2).

\section{CALORIMETRIC APPARATUS AND PROCEDURE}

The calorimetric apparatus that was assembled in this laboratory for determining heats of reaction between gases was employed in the present investigation (2), and a similar procedure was followed with regard to the calorimetric technic.

The alcohol was vaporized by passing the stream of air through a sintered glass filter placed at the bottom of a cylindrical vessel containing the pure alcohol (liquid). This saturator was immersed in water which was maintained at the temperature of the room. The air entered the bottom of the saturator, passed upward through the liquid alcohol, and was thus saturated with alcohol vapor. On leaving the saturator the combustible mixture passed first through a plug of glass wool placed beyond the upper or exit end of the saturator, and then through some $8 \mathrm{~m}$ of pyrex laboratory glass tubing at the room temperature before reaching the calorimeter.

For an actual calorimetric experiment the combustible gas was kept flowing into a waste tube until the time for initiating the reaction, when it was switched into the burner tube of the reaction vessel in the calorimeter simultaneously with the closing of the spark circuit, which, for uniformity, was closed for 10 seconds at the start of each methyl-alcohol experiment and for 5 seconds at the start of each ethyl-alcohol experiment. The combustible mixture thus ignited burned quietly in a blue flame at the burner tip. The oxygen "atmosphere" for the combustion was kept flowing, at a rate in excess of the amount required, into the side entrance tube of the reaction vessel from a time one minute before ignition to four or five minutes after extinction of the flame. When a sufficient amount of reaction had taken place, as evidenced by the temperature rise of the calorimeter, the flow of combustible gas into the calorimeter was stopped and oxygen was simultaneously sent down the burner tube. This latter operation served to burn up all the alcohol in the burner tube (the flame continued to burn one or two seconds after stopping the

11 This test was made by adding a drop or two of concentrated aqueous ammonia to the liquid water formed in the combustion of 0.1 mole of ethyl alcohol, and weighing the solid residue formed upon evaporation at $80^{\circ}$ to $90^{\circ} \mathrm{C}$. This residue, $0.3 \mathrm{mg}$, was found, by means of the phenoldisulfonic acid test, to be about two-thirds ammonium nitrate, the remainder possibly bei ng ammonium acetate. 
flow of air and alcohol). Most of the water formed was condensed to liquid in the lower chamber of the reaction vessel. All of the carbon dioxide, and some water vapor, were carried out of the reaction vessel by the excess gas. On leaving the calorimeter the gas passed first through a glass $U$ tube containing "dehydrite" (and phosphorus pentoxide), which absorbed the water, and then through a second U tube containing "ascarite" (and phosphorus pentoxide), which absorbed the carbon dioxide, and finally through a guard tube containing, in order, phosphorus pentoxide, "dehydrite," and "ascarite." When the flow of oxygen was stopped some four or five minutes after extinction of the flame, the $U$ tubes were closed.

The experiments with methyl alcohol were performed in January and February, 1931, the room temperature being $22^{\circ}$ to $24^{\circ} \mathrm{C}$. At this temperature the combustible mixture contained about 1 mole of methyl alcohol per 6 moles of air and was fed into the reaction vessel in the calorimeter at such a rate that about 0.057 mole of methyl alcohol was consumed in 30 to 32 minutes.

In order to burn ethyl alcohol in the same burner tube and at about the same rate of heat evolution, it became necessary to have a higher concentration of ethyl-alcohol vapor in the air-alcohol mixture than could be obtained at a room temperature of $22^{\circ}$ to $24^{\circ} \mathrm{C}$. The ethylalcohol experiments were carried out in August, 1931, when the temperature of the laboratory room was kept at $32^{\circ}$ to $33^{\circ} \mathrm{C}$. At this temperature, air saturated with ethyl alcohol formed a combustible mixture which was ignited more easily, under the given conditions, than air saturated with methyl-alcohol vapor at $22^{\circ}$ to $24^{\circ} \mathrm{C}$. At $32^{\circ}$ to $33^{\circ} \mathrm{C}$. the mixture of air and ethyl alcohol contained about 1 mole of alcohol per 8 moles of air, and was burned at such a rate that about 0.031 mole of ethyl alcohol was consumed in 22 to 23 minutes. ${ }^{12}$

As finally carried out, the combustions of methyl alcohol were initiated with a sparking period of 10 seconds, while a sparking period of 5 seconds was more than ample to start the combustion of the ethyl alcohol. Both these periods were in excess of the time that was actually required, on the average, for the particular conditions of the experiments, but it was deemed wise to continue the sparking for several seconds longer than necessary in order not to jeopardize the successful initiation of any given combustion experiment. The only evidence given to the operator to decide whether the combustible mixture had been properly ignited was the beginning of the sharp temperature rise in the calorimeter, which occurred about 20 seconds after the combustion began.

Because the gas which was fed into the burner tube of the reaction vessel in the alcohol experiments was a combustible mixture, a necessary change was made in the arrangement of the sparking lead running down the burner tube. Inspection of Figure 1 shows that the continuity of the two sparking leads is broken with a gap at their entrance into the reaction vessel. In the present experiments it was necessary to prevent contact of the sparks with the combustible gas before it reached the burner tip. This was accomplished by covering

\footnotetext{
12 The early attempts (February, 1931) to burn a mixture containing about 1 mole of ethyl alcohol per 14 moles of air (the mixture which would be obtained with a room temperature of $22^{\circ} \mathrm{C}$.) were unsuccessful because the flame tended to blow off this particular burner tip, even when the rate of flow was greatly reduced and when oxygen was used as a carrier. In a preliminary experiment with methyl alcohol, using oxygen as a carrier, the velocity of flow of the combustible mixture fell bilow the flame vilusity, witu tas result that the flame traveled back through the combustible mixture.
} 
the gap in the spark lead in the burner tube with a piece of capillary glass tubing, the discontinuity of the platinum wire being preserved.

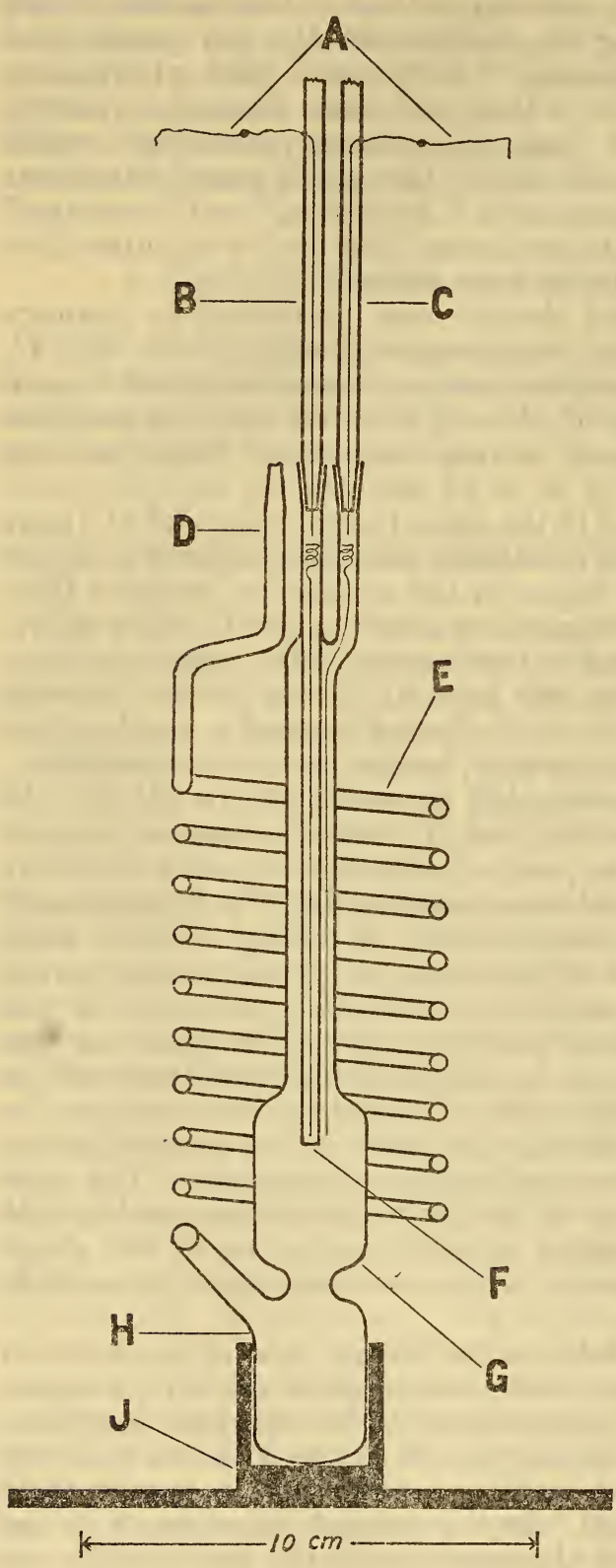

FIGURE 1.-Cross section of the reaction vessel and supporting frame

$A$, leads of spark circuit; $B, C$, inlet tubes; $D$, exit tube; $E$, cooling coil; $F$, burner tube; $G$, reaction chamber; $H$, condensing chamber; $J$, supporting frame

glass form. The potential leads (No 28, B \& S orage, enameled copper) were soldered to the current leads midway in the air gap between the bustions with methyl alcohol the combustible mixture reacted on the surface of the platinum wire running down the burner tube and prevented the maintenance of a flame at the tip. This preliminary reaction was stopped by covering the lower threefourths of the platinum lead with capillary glass tubing.

The difference in temperature between the calorimeter water and the gases issuing from the cooling coil of the reaction vessel during a combustion was found, by measurement with a single junction thermoelement made of No. 36 constantan and copper wires, to be zero within $0.05^{\circ} \mathrm{C}$. If all the issuing gases left at a temperature $0.05^{\circ} \mathrm{C}$. higher than the calorimeter water, the amount of energy lost would be 1 part in 100,000 of the total.

A new heater for imparting electrical energy to the calorimeter was built and used in the present experiments. This heater was made by winding, noninductively, No. 30, B. \& S. gage, enameled constantan wire around a cylindrical piece of pyrex laboratory glass tubing, 11/4 inches in diameter and 2 inches long, and covering the layer of wire with "pizein," a black tarlike cement having a low melting temperature and high insulation resistance, and which is insoluble in water. Enameled copper leads (No. 24, B. \& S. gage) were soldered to the ends of the constantan wire and insulated with "pizein" on the

In some of the trial com- 
calorimeter can and the jacket, and all four leads were imbedded in deKhotinsky wax which was firmly cemented to the jacket. The resistance of the heater was about $66 \mathrm{ohms}$. The amount of water absorbed by this "pizein" was found to be practically zero ( $\pm 3 \mathrm{mg}$ ) in an experiment in which about $5 \mathrm{~g}$ of the material, cut up into small pieces, was immersed in boiling water for two hours and in water at room temperature for several months. In all the experiments the heater was slipped down over the central part of the reaction vessel where it surrounded the reaction chamber.

\section{CALORIMETRIC DATA ON METHYL ALCOHOL}

\section{CORRECTION EXPERIMENTS}

In order to determine the energy introduced in to the calorimeter by the igniting operation, three experiments were made, in each of which there were two separate ignitions and extinctions of the flame, which was permitted to burn several seconds after the spark circuit was broken.

The results of the "correction" experiments are given in Table 3, the column headings of which are self-explanatory. In these experiments the amount of alcohol burned was small, and all of the water formed was carried out of the calorimeter as vapor. The method of computing the "gas" and the "vaporization" values is explained in the previouslpaper (2).

TABLE 3.-Correction experiments (for methyl alcohol)

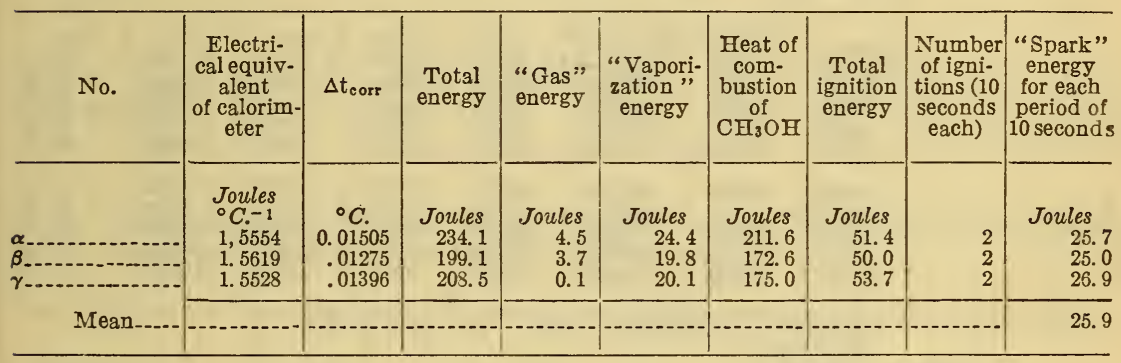

\section{ELECTRICAL ENERGY EXPERIMENTS}

The results of the experiments of the methyl alcohol group to determine the electrical energy equivalent of the calorimeter are given in Table 4. The symbols heading the various columns have already been defined (2). These data determined the electrical energy equivalent of the calorimeter for the particular conditions existing at the time of the methyl alcohol experiments.

\section{COMBUSTION EXPERIMENTS}

The data of the 10 calorimetric experiments in which methyl alcohol was burned in the calorimeter are given in Table 5.

$$
89194-31-9
$$


TABLE 4.-Electrical energy experiments (for methyl alcohol)

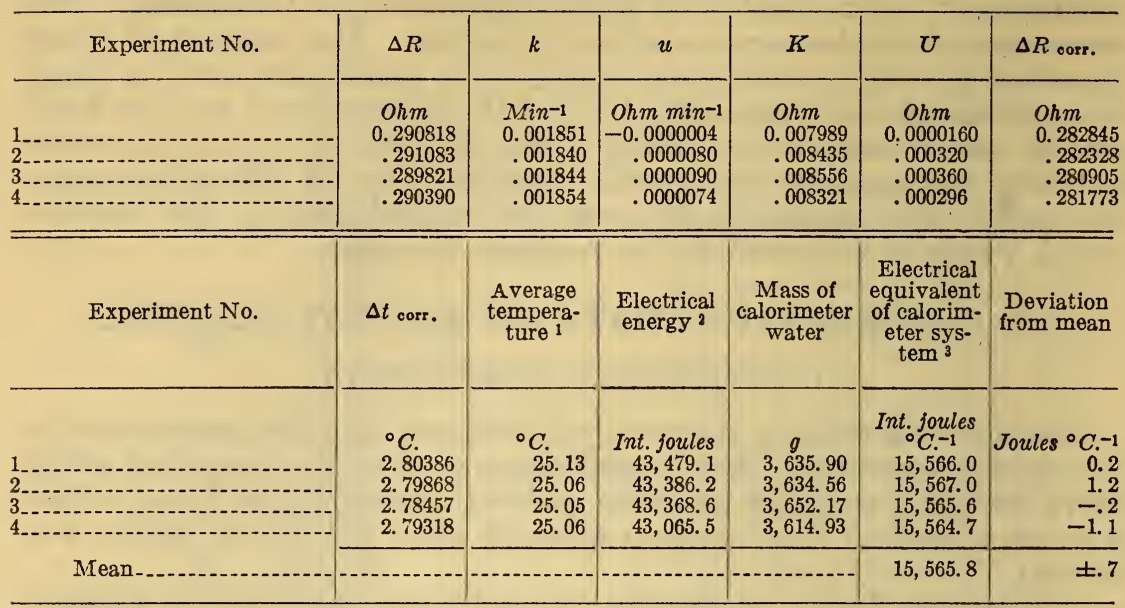

1 The room temperature was $22^{\circ}$ to $24^{\circ} \mathrm{C}$.

2 The time of electrical energy input was $1,800.00$ seconds.

3 Corrected to $3,650.00 \mathrm{~g}$ of water and an average temperature of $25.00^{\circ} \mathrm{C}$.

TABLE 5.-Reaction experiments (combustion of gaseous methyl alcohol)

\begin{tabular}{|c|c|c|c|c|c|c|c|c|c|c|}
\hline \multicolumn{2}{|c|}{ Experiment } & $\Delta R$ & \multicolumn{2}{|r|}{$k$} & $u$ & $K$ & \multicolumn{2}{|r|}{$\Delta R_{\text {oorr }}$} & $\Delta t_{\text {corr. }}$ & $\begin{array}{l}\text { Average } \\
\text { tempera- } \\
\text { ture } 1\end{array}$ \\
\hline & $\begin{array}{l}0 . \\
- \\
-\end{array}$ & $\begin{array}{l}\text { Ohm } \\
0.285721 \\
.205545 \\
.290942 \\
.286678 \\
.287472\end{array}$ & $\begin{array}{r}M \\
0.0 \\
.0 \\
.0 \\
.0 \\
.0\end{array}$ & \begin{tabular}{l|r} 
Iin-1 & Oh \\
01818 & 0. \\
01815 &. \\
01833 & \\
01837 & - \\
01823 &
\end{tabular} & $\begin{array}{r}h m \text { min }^{-1} \\
0.0000144 \\
.0000225 \\
.0000091 \\
-.0000021 \\
.0000084\end{array}$ & $\begin{array}{c}\text { Ohm } \\
0.008348 \\
.010992 \\
.008527 \\
.008494 \\
.008473\end{array}$ & $\begin{array}{c}\text { Ohm } \\
0.000576 \\
.000900 \\
.000364 \\
-.000084 \\
.000336\end{array}$ & $\begin{array}{l}\text { Ohm } \\
0.276797 \\
.193617 \\
.282051 \\
.278268 \\
.278663\end{array}$ & $\begin{array}{c}{ }^{\circ} C \text {. } \\
2.74385 \\
1.91909 \\
2.79593 \\
2.75843 \\
2.76234\end{array}$ & $\begin{array}{l}{ }^{\circ} C . \\
25.07 \\
24.66 \\
25.06 \\
25.06 \\
25.04\end{array}$ \\
\hline & & $\begin{array}{r}.289998 \\
.290717 \\
.288422 \\
.291813 \\
.291169\end{array}$ & & $\begin{array}{l}01808 \\
01827 \\
01845 \\
01885 \\
01848\end{array}$ & $\begin{array}{l}.0000149 \\
.0000013 \\
.0000040 \\
.0000042 \\
.0000030\end{array}$ & $\begin{array}{l}.008715 \\
.008660 \\
.009432 \\
.008829 \\
.008523\end{array}$ & $\begin{array}{l}.000596 \\
.000052 \\
.000160 \\
.000168 \\
.000120\end{array}$ & $\begin{array}{l}.280687 \\
.282005 \\
.278830 \\
.282816 \\
.282526\end{array}$ & $\begin{array}{l}2.78241 \\
2.79545 \\
2.76398 \\
2.80352 \\
2.80064\end{array}$ & $\begin{array}{l}25.06 \\
25.02 \\
25.02 \\
25.07 \\
25.06\end{array}$ \\
\hline Experiment & $\begin{array}{l}\text { Mass of } \\
\text { calori- } \\
\text { meter } \\
\text { water }\end{array}$ & $\begin{array}{r}\text { Electr } \\
\text { equi } \\
\text { lent } \\
\text { calo } \\
\text { met } \\
\text { syste }\end{array}$ & & $\begin{array}{c}\text { Total } \\
\text { energy } 2\end{array}$ & $\begin{array}{l}\text { "Gas" } \\
\text { energy }\end{array}$ & $\begin{array}{l}\text { "Vapor- } \\
\text { ization" } \\
\text { energy }\end{array}$ & $\begin{array}{l}\text { "Spark" } \\
\text { energy }\end{array}$ & $\begin{array}{l}\text { Mass of } \\
\mathrm{CO}_{2} \\
\text { formed }\end{array}$ & $\begin{array}{c}Q_{25^{\circ}} \mathrm{C} . \\
1 \text { atm. }\end{array}$ & $\begin{array}{l}\text { Deviation } \\
\text { from } \\
\text { mean }\end{array}$ \\
\hline & $\begin{array}{c}g \\
3,640.51 \\
3,659.03 \\
3,657.02 \\
3,651.38 \\
3,654.07\end{array}$ & \begin{tabular}{r|r} 
& Int. jo \\
& ${ }^{\circ} \mathbf{C}$ \\
1 & 15,53 \\
3 & 15,60 \\
2 & 15,59 \\
8 & 15,57 \\
7 & 15,58
\end{tabular} & & $\begin{array}{c}\text { Int. joules } \\
42,612.3 \\
29,950.7 \\
43,613.7 \\
42,963.1 \\
43,055.5\end{array}$ & $\begin{array}{rr}\text { Joules } \\
7.5 \\
70.1 \\
23.9 \\
16.1 \\
29.5\end{array}$ & $\begin{array}{c}\text { Int. } \\
\text { joules } \\
515.8 \\
441.9 \\
461.9 \\
616.1 \\
543.4\end{array}$ & $\begin{array}{r}\text { Joules } \\
25.9 \\
25.9 \\
25.9 \\
25.9 \\
25.9\end{array}$ & $\begin{array}{c}\text { Mole } \\
0.056468 \\
.039796 \\
.057763 \\
.057042 \\
.057099\end{array}$ & $\begin{array}{c}\text { Int. kilo- } \\
\text { joules } \\
\text { mole-1 } \\
763.44 \\
763.82 \\
(763.01) \\
763.81 \\
763.63\end{array}$ & $\begin{array}{r}\text { Kilojoules } \\
\text { mole-1 } \\
-0.24 \\
.14 \\
-.13 \\
-.05\end{array}$ \\
\hline & $\begin{array}{l}3,651.72 \\
3,644.11 \\
3,643.91 \\
3,634.70 \\
3,617.11\end{array}$ & \begin{tabular}{l|l}
2 & 15,57 \\
1 & 15,54 \\
1 & 15,54 \\
0 & 15,50 \\
1 & 15,43
\end{tabular} & & $\begin{array}{l}43,340.8 \\
43,455.3 \\
42,963.6 \\
43,470.3 \\
43,219.8\end{array}$ & $\begin{array}{l}16.0 \\
22.5 \\
38.7 \\
36.5 \\
15.5\end{array}$ & $\begin{array}{l}544.6 \\
539.5 \\
621.0 \\
615.8 \\
584.9\end{array}$ & $\begin{array}{l}25.9 \\
25.9 \\
25.9 \\
25.9 \\
25.9\end{array}$ & $\begin{array}{l}.057442 \\
.057615 \\
.057081 \\
.057760 \\
.057335\end{array}$ & $\begin{array}{l}763.82 \\
763.54 \\
763.78 \\
763.45 \\
763.83\end{array}$ & $\begin{array}{r}.14 \\
-.14 \\
.10 \\
-.23 \\
.15\end{array}$ \\
\hline I & & & & & & & & & 763.68 & \pm .15 \\
\hline
\end{tabular}

1 The room temperature was $22^{\circ}$ to $24^{\circ} \mathrm{C}$.

2 The time of reaction was 30 to 31 minutes.

3 The result of experiment $\mathrm{C}$ is not included, 
The "vaporization" energy was equal to the heat of vaporization of that mass of water, $m_{v}$, formed in the combustion, which was not condensed to liquid during the calorimetric experiment. The increase in mass of the solid absorbent in the first $U$ tube was not exactly equal to $m_{0}$ because first, the alcohol itself might contain water, and second, a small amount of alcohol vapor $(<2 \mathrm{mg})$ came through unburned at the beginning of each combustion experiment and was completely absorbed in the "dehydrite." The method of determining $m_{0}$ in the methyl-alcohol experiments is as follows:

$m_{a}$ is the mass of the solid absorbent in the first $U$ tube at the beginning of the calorimetric experiment.

$m_{b}$ is the mass of water which was contained as vapor in the reaction vessel at the conclusion of the calorimetric experiment.

$m_{c}$ is the mass of unburned alcohol which was absorbed in the first $U$ tube.

$m_{d}$ is the mass of water contained in the alcohol vapor consumed in the given experiment.

$n$ is the number of moles of carbon dioxide formed in the experiment. $m_{e}$ is the mass of the solid absorbent in the first $U$ tube at the end of the calorimetric experiment.

$m_{f}$ is the mass of the solid absorbent in the first $U$ tube after all the water has been carried from the reaction vessel into the first $U$ tube. $M_{w}$ is the molecular weight of water.

The quantities determined experimentally are $m_{a}, m_{b}, m_{e}, m_{f}$, and $n$. These are related by the following equations:

Therefore

$$
\begin{aligned}
& m_{e}-m_{a}=m_{0}-m_{b}+\left(m_{c}+m_{d}\right) \\
& m_{f}-m_{a}=2 n M_{w}+\left(m_{c}+m_{d}\right)
\end{aligned}
$$

$$
m_{0}=m_{e}-m_{\rho}+m_{b}+2 n M_{w}
$$

In the present method, the amount of water contained in the alcohol is not involved in the calorimetric calculation.

\section{RESULTS OF THE PRESENT WORK}

From the data of the present experiments, the heat evolved in the reaction

$$
\mathrm{CH}_{3} \mathrm{OH}_{(\vartheta)}+3 / 2 \mathrm{O}_{2(\vartheta)}=\mathrm{CO}_{2(g)}+2 \mathrm{H}_{2} \mathrm{O}_{(l)}
$$

at $25^{\circ} \mathrm{C}$. and a constant total pressure of 1 atmosphere, with the alcohol near saturation pressure, is found to be 763.68 international kilojoules per mole of methyl alcohol. The average deviation for the 10 experiments was \pm 0.15 kilojoule per mole. The preliminary value previously reported (11) for the heat of the above reaction was given as 763.77 , but this included a wrong pressure correction (12). The value 763.68 is the one which is correctly obtained from the present data.

For the group of experiments on methyl alcohol, the "error" (2), $\pm 2 \sqrt{\frac{\overline{\Sigma(x-\bar{x})^{2}}}{n(n-1)}}$, is equal to \pm 0.007 per cent for the electrical energy experiments, and to \pm 0.015 per cent for the combustion experiments. The "combined error," taken as the square root of the sum of the 
squares of the two percentage errors, is \pm 0.017 per cent, or \pm 0.13 kilojoule per mole. The value given for the heat of combustion of methyl alcohol is conservatively estimated to be reliable within \pm 0.20 kilojoule per mole. The heat of demixing air and alcohol vapor is considered negligible.

From the data of Fiock, Ginnings, and Holton (3), the heat evolved in the process

$$
\mathrm{CH}_{3} \mathrm{OH}_{(l)}=\mathrm{CH}_{3} \mathrm{OH}_{(g)}
$$

at $25^{\circ} \mathrm{C}$. and saturation pressure is

$$
Q=-37.43 \pm 0.03 \text { international kilojoules per mole }
$$

Addition of equations (1) and (2) gives for the reaction

$$
\mathrm{CH}_{3} \mathrm{OH}_{(l)}+3 / 2 \mathrm{O}_{2(\vartheta)}=\mathrm{CO}_{2(\vartheta)}+2 \mathrm{H}_{2} \mathrm{O}_{(l)}
$$

at $25^{\circ} \mathrm{C}$. and a constant pressure of 1 atmosphere

$$
Q=726.25 \pm 0.20 \text { international kilojoules per mole }
$$

The change in heat content of the liquid from saturation pressure to 1 atmosphere is negligible.

\section{DATA OF PREVIOUS INVESTIGATORS}

The heat of combustion of methyl alcohol has been the subject of experiments reported by Favre and Silbermann (13) in 1852; Thomsen (14) in 1880; Stohmann, Kleber, and Langbein (15) in 1889; Richards and Davis (16) in 1920; Roth and Müller (17) in 1927; and Roth and Banse (18), and the I. G. Farbenfabrik (18), in 1931. All of these investigators employed the bomb method, except Favre and Silbermann, and Thomsen, who burned the alcohol in a flame at constant pressure.

Favre and Silbermann (13) had not the advantages of modern calorimetric technic nor of pure material to work with, so their results have only a historical interest.

Thomsen (14), by sending the vapor of methyl alcohol at its boiling point into the calorimeter to be burned in oxygen at constant pressure, measured, for the heat evolved in the reaction,

$$
\begin{aligned}
& \left.\mathrm{CH}_{3} \mathrm{OH}_{\left(g, 65^{\circ} \text { c. }\right)}+3 / 2 \mathrm{O}_{2\left(0,18^{\circ} c .\right.}\right)=\mathrm{CO}_{2\left(\ell, 18^{\circ} c .\right)}+2 \mathrm{H}_{2} \mathrm{O}\left(l, 18^{\circ} c .\right) \\
& Q=182.92 \mathrm{~kg}-\mathrm{cal}_{18} \text { per mole }
\end{aligned}
$$

This was the average of eight experiments. The data on the heat content and the heat of vaporization of methyl alcohol, which were obtained by Fiock, Ginnings, and Holton (3), can be combined with the data of Thomsen to give the heat of combustion of liquid methyl alcohol at $18^{\circ} \mathrm{C}$. For the process

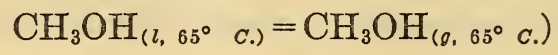

and for

$$
Q=-35.23 \text { international kilojoules per mole }
$$

$$
\left.\mathrm{CH}_{3} \mathrm{OH}_{\left(l, 18^{\circ}\right.} \text { c. }\right)=\mathrm{CH}_{3} \mathrm{OH}_{\left(l, 65^{\circ}\right.} \text { c.) }
$$

$$
Q=-3.95 \text { kilojoules per mole }
$$


Conversion of kg-cal. ${ }_{18}$ to international kilojoules, and addition of these equations, give for the heat of combustion of liquid methyl alcohol at $18^{\circ} \mathrm{C}$., the value 725.44 . For the reaction at $25^{\circ} \mathrm{C}$., this becomes 725.2 international kilojoules per mole. The "error," estimated by the present author, is \pm 1.6 kilojoules per mole. The data which Thomsen obtained by his "universal burner" method has been subject to the criticism that the results obtained are too high because of an unaccounted-for flow of heat from the boiler to the calorimeter, the higher boiling liquids giving increasingly too high results.

Stohmann, Kleber, and Langbein (15), in carrying out their experiments, placed the alcohol in the bomb in a sealed glass bulb. After oxygen to the desired pressure had been added, the glass bulb was broken by shaking the bomb. Before the actual calorimetric experiment was begun, then, the interior of the bomb was saturated with alcohol vapor, the heat of vaporization of which was properly accounted for. According to Richards and Jesse (19) the method used by Stohmann for burning volatile liquids leads to incomplete combustion and consequent low results. From the data of six experiments, Stohmann, Kleber, and Langbein give an average value of $5.3215 \mathrm{~kg}$-cal.15 per $\mathrm{g}$ of alcohol (weighed in air?) at constant volume in the bomb, the final temperature of the calorimeter being about $18^{\circ} \mathrm{C}$. Converted to international kilojoules per mole at $25^{\circ} \mathrm{C}$. and constant pressure, the value becomes 714 . The estimated "error" is. \pm 2 kilojoules per mole.

Richards and Davis (16) performed five experiments by burning methyl alcohol in a bomb at constant volume, using accurate calorimetric technic and an improved method of placing the liquid alcohol in a glass bulb in the bomb, the tip of the bulb being broken at the time of ignition. Although this procedure worked admirably well for the higher boiling liquids with which they experimented, Richards and Davis reported for methyl alcohol, that "The combustions with this substance were the least satisfactory, perhaps because of its volatility. Unfortunately only one could be analyzed for carbon monoxide, because of lack of time." In this one experiment quite an appreciable amount of carbon monoxide was found, the heat correction being about one-fourth per cent. Richards and Davis gave the density of the methyl alcohol burned by them as $d_{4}^{20}=0.7923$. This value is 0.12 per cent higher than the present "best" value (7). If the increased density were due to water, then the value for the heat of combustion of methyl alcohol from these data would be too low by a percentage amount corresponding to the weight per cent of water present. Richards and Davis reported for the heat of combustion of liquid methyl alcohol in their bomb at constant volume, the value $5.333 \mathrm{~kg}$-cal. 18 per $\mathrm{g}$ (weighed in air) at $20^{\circ} \mathrm{C}$. Converted to international kilojoules, the heat of combustion at $25^{\circ} \mathrm{C}$. and constant pressure becomes 714.2 international kilojoules per mole. The estimated "error" is \pm 2 kilojoules per mole.

The details of the experiments performed by Roth and Müller (17), Roth and Banse (18), and the I. G. Farbenfabrik (18), have not been published, but the values are reported in the Landolt-Börntsein-RothScheel tables. Roth and Müller give 5.365, Roth and Banse 5.431, and the I. G. Farbenfabrik 5.423, kg-cal.15 per g of methyl alcohol (weighed in air) at $20^{\circ} \mathrm{C}$. and constant volume. When converted to 
international kilojoules per mole at $25^{\circ} \mathrm{C}$. and constant pressure, these values become $719,727.8$, and 726.7 , respectively. Roth and Banse have recalculated their value since its appearance in the Landolt-Börnstein-Roth-Scheel tables, and in a private communication to the present author give the value $5.418 \mathrm{~kg}$-cal. 15 per $\mathrm{g}$ (weighed in air) at $20^{\circ}$. C. and constant volume. Their corrected value becomes 726 international kilojoules per mole at $25^{\circ} \mathrm{C}$. and a constant pressure of 1 atmosphere.

In Figure 2 are plotted the results of the foregoing investigations on methyl alcohol, together with that of the present work.

\section{CALORIMETRIC DATA ON ETHYL ALCOHOL}

\section{CORRECTION EXPERIMENTS}

The energy introduced into the calorimeter by the igniting operation was determined from one calorimetric experiment which consisted of six separate ignitions and extinctions of the flame. These data are given in Table 6 .

TABLE 6.-Correction experiments (for ethyl alcohol)

\begin{tabular}{|c|c|c|c|c|c|c|c|c|c|}
\hline No. & $\begin{array}{l}\text { Electrical } \\
\text { equivalent } \\
\text { of calori- } \\
\text { meter }\end{array}$ & $\Delta t_{\text {corr }}$ & $\begin{array}{l}\text { Total } \\
\text { energy }\end{array}$ & $\begin{array}{l}\text { "Gas" } \\
\text { energy }\end{array}$ & $\begin{array}{c}\text { "Vapori- } \\
\text { zation" } \\
\text { energy }\end{array}$ & $\begin{array}{l}\text { Heat of } \\
\text { combus- } \\
\text { tion of } \\
\mathrm{C}_{2} \mathrm{H}_{5} \mathrm{OH}\end{array}$ & $\begin{array}{c}\text { Total } \\
\text { ignition } \\
\text { energy }\end{array}$ & $\begin{array}{l}\text { Number } \\
\text { of igni- } \\
\text { tions (5 } \\
\text { seconds } \\
\text { each) }\end{array}$ & $\begin{array}{l}\text { "Spark" } \\
\text { energy } \\
\text { for each } \\
\text { period of } \\
5 \text { seconds }\end{array}$ \\
\hline$\alpha$ & $\begin{array}{c}\text { Joules }{ }^{\circ} C^{-1} \\
15,420.0\end{array}$ & $\begin{array}{c}{ }^{\circ} C . \\
0.05181\end{array}$ & $\begin{array}{c}\text { Joules } \\
798.9\end{array}$ & $\begin{array}{r}\text { Joules } \\
4.7\end{array}$ & $\begin{array}{c}\text { Joules } \\
77.7\end{array}$ & $\begin{array}{c}\text { Joules } \\
836.9\end{array}$ & $\begin{array}{r}\text { Joules } \\
44.4\end{array}$ & 6 & $\begin{array}{c}\text { Joules } \\
7.4\end{array}$ \\
\hline
\end{tabular}

\section{ELECTRICAL ENERGY EXPERIMENTS}

The electrical energy equivalent of the calorimeter for the conditions prevailing at the time of the ethyl alcohol experiments was determined from the data given in Table 7.

TABLE 7.-Electrical energy experiments (for ethyl alcohol)

\begin{tabular}{|c|c|c|c|c|c|c|}
\hline Experiment No. & $\Delta R$ & $k$ & $u$ & $K$ & $U$ & $\Delta R_{\text {oorr }}$ \\
\hline 5 & $\begin{array}{l}\text { Ohms } \\
0.289065 \\
.288833 \\
.288994 \\
.288195 \\
.288267\end{array}$ & $\begin{array}{l}\text { Min.-1 } \\
0.001946 \\
.001966 \\
.001969 \\
.001980 \\
.001972\end{array}$ & $\begin{array}{c}\text { Ohm min } .^{-1} \\
0.0000017 \\
.0000139 \\
.0000091 \\
.0000044 \\
.0000035\end{array}$ & $\begin{array}{c}\text { Ohm } \\
0.007163 \\
.007066 \\
.007094 \\
.007086 \\
.007157\end{array}$ & $\begin{array}{l}\text { Ohm } \\
0.000051 \\
.000417 \\
.000273 \\
.000132 \\
.000105\end{array}$ & $\begin{array}{l}\text { Ohm } \\
0.281851 \\
.281350 \\
.281627 \\
.280977 \\
.281110\end{array}$ \\
\hline Experiment No. & $\Delta t_{\text {corr. }}$ & $\begin{array}{l}\text { Average } \\
\text { tempera- } \\
\text { ture }^{1}\end{array}$ & $\begin{array}{l}\text { Electrical } \\
\text { energy }^{2}\end{array}$ & $\begin{array}{c}\text { Mass of } \\
\text { calorimeter } \\
\text { water }\end{array}$ & $\begin{array}{l}\text { Electrical } \\
\text { equivalent } \\
\text { of calorim- } \\
\text { eter } \\
\text { system }\end{array}$ & $\begin{array}{l}\text { Deviation } \\
\text { from mean }\end{array}$ \\
\hline $\begin{array}{l}1 \\
2-\cdots- \\
3-\cdots \\
4-\cdots \\
5-\cdots\end{array}$ & $\begin{array}{l}\circ C . \\
2.80011 \\
2.79514 \\
2.79789 \\
2.79143 \\
2.79275\end{array}$ & $\begin{array}{l}{ }^{\circ} C . \\
32.51 \\
32.52 \\
32.52 \\
32.52 \\
32.52\end{array}$ & $\begin{array}{r}\text { Int. joules } \\
43386.1 \\
43301.3 \\
43311.5 \\
43210.1 \\
43210.6\end{array}$ & $\begin{array}{c}g \\
3633.12 \\
3632.55 \\
3630.70 \\
3630.80 \\
3629.05\end{array}$ & $\begin{array}{c}\text { Int. joules } \\
\text { o. } \text {-1 }^{-1} \\
15481.4 \\
15481.0 \\
15477.2 \\
15476.3 \\
15476.4\end{array}$ & $\begin{array}{r}2.9 \\
2.5 \\
-1.3 \\
-2.2 \\
-2.1\end{array}$ \\
\hline Mean... & & & & - & 15478.5 & \pm 2.2 \\
\hline
\end{tabular}

1 The room temperature was $32^{\circ}$ to $33^{\circ} \mathrm{C}$.

2 In each experiment the time of electrical energy input was $1,380.00$ seconds.

3 Corrected to $3,630 \mathrm{~g}$ water and an average temperature of $32.50^{\circ} \mathrm{C}$. 


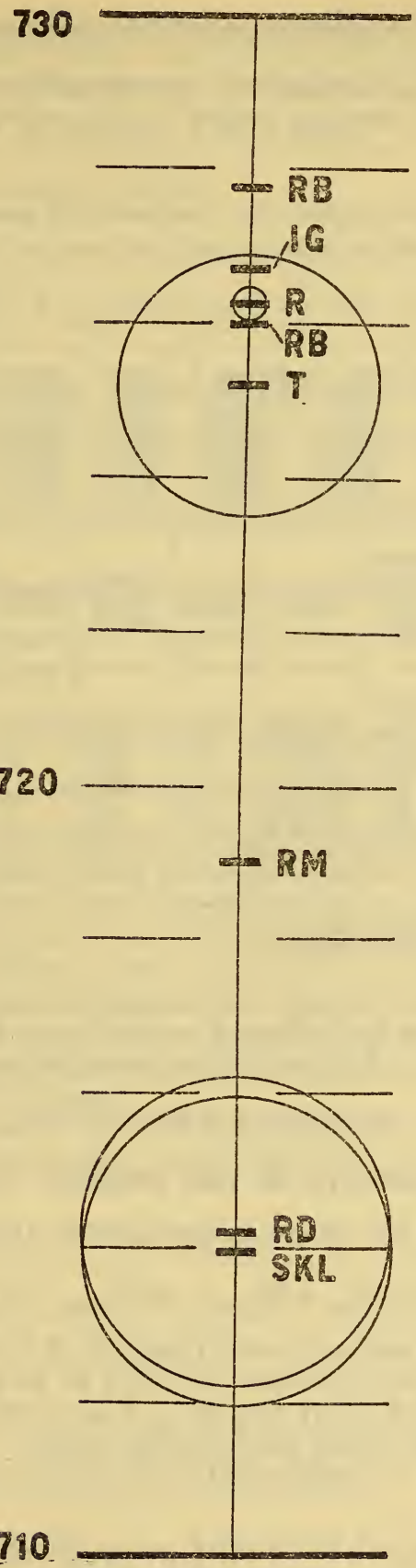

Figure 2.-Plot of the data on methyl alcohol The ordinate scale gives the heat of combustion of liquid methyl alcohol at $25^{\circ} \mathrm{C}$. and a constant pressure of 1 atmosphere, in international kilojoules per mole. The circles measure the assigned "error" of the respective average values which are indicated for the following investigations: SKL, Stohmann, Kleber, and Langbein; IG, I. G. Farbenfabrik; $R D$, Richards and Davis; $R B$, Roth and Banse; $R M$, Roth and Müller; $T$, Thomsen; $R$, Rossini. 


\section{COMBUSTION EXPERIMENTS}

The data of the six calorimetric experiments in which ethyl alcohol was burned in the reaction vessel in the calorimeter are given in Table 8.

TABLE 8.-Reaction experiments (combustion of gaseous ethyl alcohol)

\begin{tabular}{|c|c|c|c|c|c|c|c|c|c|c|c|c|}
\hline \multicolumn{2}{|c|}{ Experiment No. } & & $\Delta R$ & \multicolumn{2}{|c|}{$k$} & \multicolumn{2}{|c|}{$u$} & $K$ & $U$ & $\Delta R_{\text {corr }}$ & $\Delta t_{\text {corr. }}$ & $\begin{array}{l}\text { A verage } \\
\text { temper- } \\
\text { ature }{ }^{1}\end{array}$ \\
\hline \multicolumn{2}{|c|}{$\begin{array}{l}\text { A } \\
\text { B } \\
\text { B } \\
\text { D } \\
\text { F }\end{array}$} & \multicolumn{2}{|c|}{$\begin{array}{l}\text { Ohm } \\
0.286865 \\
.293712 \\
.287405 \\
.293056 \\
.288895 \\
.287143\end{array}$} & \multicolumn{2}{|c|}{$\begin{array}{l}\text { Min.-1 } \\
0.001984 \\
.001969 \\
.001985 \\
.001980 \\
.001982 \\
.001981\end{array}$} & \multicolumn{2}{|c|}{$\begin{array}{c}\text { Ohm min.-1 } \\
0.0000064 \\
.0000024 \\
.0000069 \\
.0000000 \\
.0000027 \\
.0000019\end{array}$} & \begin{tabular}{c|} 
Ohm \\
0.007385 \\
.006585 \\
.006360 \\
.006743 \\
.007692 \\
.007388
\end{tabular} & $\begin{array}{l}\text { Ohm } \\
0.000230 \\
.000086 \\
.000248 \\
.000000 \\
.000097 \\
.000068\end{array}$ & $\begin{array}{l}\text { Ohm } \\
0.279250 \\
.287041 \\
.280797 \\
.286313 \\
.281106 \\
.279687\end{array}$ & $\begin{array}{l}{ }^{\circ} C . \\
2.77427 \\
2.85167 \\
2.78967 \\
2.84447 \\
2.79271 \\
2.77861\end{array}$ & $\begin{array}{l}{ }^{\circ} \mathrm{C} . \\
32.52 \\
32.52 \\
32.52 \\
32.54 \\
32.52 \\
32.51\end{array}$ \\
\hline $\begin{array}{c}\text { Experiment } \\
\text { No. }\end{array}$ & \multicolumn{2}{|c|}{$\begin{array}{l}\text { Mass of } \\
\text { calorim- } \\
\text { eter } \\
\text { water }\end{array}$} & \multicolumn{2}{|c|}{$\begin{array}{c}\text { Electrical } \\
\text { equivalent } \\
\text { of calori- } \\
\text { metric } \\
\text { system }\end{array}$} & \multicolumn{2}{|c|}{$\begin{array}{c}\text { Total } \\
\text { energy } 2\end{array}$} & $\begin{array}{l}\text { Gas } \\
\text { energy }\end{array}$ & $\begin{array}{l}\text { Vapori- } \\
\text { zation } \\
\text { energy }\end{array}$ & $\begin{array}{l}\text { Spark } \\
\text { energy }\end{array}$ & $\begin{array}{c}\text { One-half } \\
\text { mass of } \\
\mathrm{CO}_{2} \\
\text { formed }\end{array}$ & $\begin{array}{l}Q_{32.5^{\circ} \mathrm{C} .} \\
1 \text { atm. }\end{array}$ & $\begin{array}{l}\text { Devia- } \\
\text { tion } \\
\text { from } \\
\text { mean }\end{array}$ \\
\hline $\mathrm{E}$ & $\begin{array}{l}3,66 \\
3,636 \\
3,62 \\
3,630 \\
3,63 \\
3,61\end{array}$ & & $\begin{array}{c}\text { Int. }{ }^{j} \\
15, \\
15, \\
15, \\
15, \\
15, \\
15,\end{array}$ & $\begin{array}{l}\text { oules } \\
-1 \\
25.8 \\
2506.6 \\
57.6 \\
185.0 \\
96.4 \\
23.7\end{array}$ & $\begin{array}{l}\text { Int. } \\
43,3 \\
44,2 \\
43,1 \\
44,0 \\
43,2 \\
42,8\end{array}$ & $\begin{array}{l}\text { joules } \\
350.2 \\
219.7 \\
21.6 \\
216.6 \\
77.0 \\
556.4\end{array}$ & $\begin{array}{r}\text { Joules } \\
3.4 \\
2.2 \\
-0.5 \\
1.6 \\
-2.2 \\
-2.1\end{array}$ & \begin{tabular}{|c|} 
Int. joules \\
854.5 \\
785.6 \\
765.7 \\
797.3 \\
778.0 \\
771.4
\end{tabular} & \begin{tabular}{|r} 
Joules \\
7.4 \\
7.4 \\
7.4 \\
7.4 \\
7.4 \\
7.4
\end{tabular} & $\begin{array}{c}\text { Mole } \\
0.0314062 \\
.0319617 \\
.0311800 \\
.0318543 \\
.0312992 \\
.0309934\end{array}$ & $\begin{array}{c}\text { Int. joules } \\
\text { mole } \\
1,407.39 \\
1,407.94 \\
1,407.29 \\
1,407.80 \\
1,407.24 \\
1,407.34\end{array}$ & $\begin{array}{r}-0.09 \\
.44 \\
-.21 \\
.30 \\
-.26 \\
-.13\end{array}$ \\
\hline & & & & & & & & & & & $1,407.50$ & \pm .26 \\
\hline
\end{tabular}

1 The room temperature was $32^{\circ}$ to $33^{\circ} \mathrm{C}$.

2 The time of reaction was 22 to 23 minutes.

The "vaporization" energy was computed as for the methyl alcohol experiments. ${ }^{13}$ Here the mass of water, formed in the combustion, but not condensed to liquid during the calorimetric experiment, was

$$
m_{v}=m_{e}-m_{f}+m_{b}+3 / 2 n M_{w}
$$

\section{RESULTS OF THE PRESENT WORK}

From the data of the present experiments, the heat evolved in the reaction

$$
\mathrm{C}_{2} \mathrm{H}_{5} \mathrm{OH}_{(\vartheta)}+3 \mathrm{O}_{2(\theta)}=2 \mathrm{CO}_{2(\theta)}+3 \mathrm{H}_{2} \mathrm{O}_{(\ell)}
$$

at $32.50^{\circ} \mathrm{C}$. and a constant total pressure of 1 atmosphere, with the alcohol near saturation pressure, is found to be 1407.50 international kilojoules per mole of ethyl alcohol. The average deviation for the six experiments was \pm 0.26 kilojoule per mole.

For the group of experiments on ethyl alcohol the "error," $\pm 2 \sqrt{\frac{\Sigma(x-\bar{x})^{2}}{n(n-1)}}$, is equal to \pm 0.014 per cent for the electrical energy experiments and to \pm 0.017 per cent for the combustion experiments. The "combined error" is \pm 0.022 per cent, or \pm 0.31 kilojoule per 
mole. The value given for the heat of combustion of ethyl alcohol is estimated to be reliable within \pm 0.40 kilojoule per mole.

Fiock, Ginnings, and Holton give for the heat evolved in the process

$$
\mathrm{C}_{2} \mathrm{H}_{5} \mathrm{OH}_{(l)}=\mathrm{C}_{2} \mathrm{H}_{5} \mathrm{OH}_{(\vartheta)}
$$

at $32.50^{\circ} \mathrm{C}$. and saturation pressure

$$
Q=-41.92 \pm 0.04 \text { international kilojoules per mole }
$$

Addition of equations (7) and (8) gives for the reaction

$$
\mathrm{C}_{2} \mathrm{H}_{5} \mathrm{OH}_{(l)}+3 \mathrm{O}_{2(g)}=2 \mathrm{CO}_{2(g)}+3 \mathrm{H}_{2} \mathrm{O}_{(l)}
$$

at $32.50^{\circ} \mathrm{C}$. and a constant pressure of 1 atmosphere

$$
Q=1365.58 \pm 0.40 \text { international kilojoules per mole }
$$

Since $\Delta \mathrm{C}_{p}\left(-=\frac{d Q}{d T}\right)$ for reaction (9) is 97.3 joules per mole per degree, then the heat of combustion of liquid alcohol at $25^{\circ} \mathrm{C}$. and a constant pressure of 1 atmosphere is

$$
Q=1366.31 \pm 0.40 \text { international kilojoules per mole }
$$

\section{DATA OF PREVIOUS INVESTIGATORS}

Values for the heat of combusion of ethyl alcohol have been reported by Andrews (20) in 1848, Favre and Silbermann (13) in 1852, Thomsen (14) in 1880, Berthelot and Matignon (21) in 1892, Atwater and Rosa (22) in 1899, Atwater and Snell (23) in 1903, Emery and Benedict (24) in 1911, Richards and Davis (16) in 1920, and Roth and Müller (17) in 1927.

As in the case of the early date on methyl alcohol, the experiments of Andrews (20), and of Favre and Silbermann (13), on ethyl alcohol are only of historical interest.

Thomsen's experiments (14) with ethyl alcohol were carried out in a manner similar to those with methyl alcohol. For the heat evolved in the reaction

$$
\mathrm{C}_{2} \mathrm{H}_{5} \mathrm{OH}_{\left(g, 78^{\circ} \mathrm{C} .\right)}+3 \mathrm{O}_{2\left(g, 18^{\circ} \mathrm{C} .\right)}=2 \mathrm{CO}_{2\left(g, 18^{\circ} \mathrm{C} .\right)}+3 \mathrm{H}_{2} \mathrm{O}_{\left(l, 18^{\circ} \mathrm{C} .\right)}
$$

Thomsen reported the average value of 10 experiments to be

$$
Q=341.79 \mathrm{~kg}-\mathrm{cal}_{18} \text { per mole }
$$

Utilizing, as for methyl alcohol, the data obtained by Fiock, Ginnings and Holton on the heat content and the heat of vaporization of ethyl alcohol, one computes for the process

$$
\mathrm{C}_{2} \mathrm{H}_{5} \mathrm{OH}_{\left(l, 78^{\circ} \mathrm{C} .\right)}=\mathrm{C}_{2} \mathrm{H}_{5} \mathrm{OH}_{\left(g, 78^{\circ} \mathrm{C} .\right)}
$$

and for

$$
Q=-38.72 \text { international kilojoules per mole }
$$

$$
\mathrm{C}_{2} \mathrm{H}_{5} \mathrm{OH}_{\left(l, 18^{\circ} \mathrm{C} .\right)}=\mathrm{C}_{2} \mathrm{H}_{5} \mathrm{OH}_{\left(l, 78^{\circ} . \mathrm{C}\right)}
$$

$$
Q=-7.37 \text { kilojoules per mole }
$$


Then, from these data, the heat of combustion of liquid ethyl alcohol at $18^{\circ} \mathrm{C}$. becomes $1,382.6$ international kilojoules per mole. For the reaction at $25^{\circ} \mathrm{C}$., the value reduces to $1,381.9$. The estimated "error" is \pm 2.2 kilojoules per mole.

Berthelot and Matignon (21) performed two experiments by absorbing the ethyl alcohol in pellets of cellulose and burning these in their bomb at constant volume. The data of these investigators appear to give the value $7.068 \mathrm{~kg}$-cal ${ }_{13}$ for the heat of combustion of $1 \mathrm{~g}$ of ethyl alcohol (weighed in air?) at $14^{\circ} \mathrm{C}$. and constant volume. Converted to international kilojoules per mole at $25^{\circ} \mathrm{C}$. and constant pressure, this value becomes 1,362 . The "error" of this value is taken as \pm 4 kilojoules per mole.

Atwater and Rosa (22) reported the results of 20 experiments in which alcohol containing about 10 per cent of water was burned in a bomb at constant volume-in some experiments the alcohol was absorbed in cellulose filter blocks and in others gelatin capsules were used to contain the alcohol before it was placed in the bomb. The percentage content of alcohol was determined from the density of the various samples. The average of these experiments was 7.067 $\mathrm{kg}$-cal ${ }_{20}$ per g of ethyl alcohol (weighed in air) at $20^{\circ} \mathrm{C}$. and constant volume. This value should be increased by 0.02 per cent because of the heat effect of diluting the alcohol with water. Converted to $25^{\circ} \mathrm{C}$. and constant pressure, these data give for the heat of combustion of liquid ethyl alcohol the value 1,360 international kilojoules per mole. The estimated "error" is \pm 4 kilojoules per mole.

Atwater and Snell (23) reported, without detail, the results of six experiments on the combustion of ethyl alcohol in their bomb at constant volume. Their data, corrected to $25^{\circ} \mathrm{C}$. and constant pressure, in international kilojoules per mole, give the value 1,363 . The estimated "error" of this value is \pm 4 kilojoules per mole.

Atwater and Snell also reported (23), without detail, the results of 11 series of experiments made at constant pressure in the respiration calorimeter of Atwater and Rosa (22). From their figures, the heat of combustion of liquid ethyl alcohol at $25^{\circ} \mathrm{C}$. and constant pressure becomes 1,361 international kilojoules per mole, with an estimated "error" of \pm 5 kilojoules per mole.

Richards and Davis (16) gave the results of four experiments performed with the calorimetric apparatus and procedure used with methyl alcohol. The average value was $7.110 \mathrm{~kg}$-cal.18 per $\mathrm{g}$ of ethyl alcohol (weighed in air) at $20^{\circ} \mathrm{C}$. and constant volume. When corrected to $25^{\circ} \mathrm{C}$. and constant pressure, and to international kilojoules, this value becomes $1,368.4$ international kilojoules per mole. The estimated "error" is \pm 1.8 kilojoules per mole.

Emery and Benedict (24) report, without experimental details, the value $7.104 \mathrm{~kg}^{-} \mathrm{cal}_{20}$ per $\mathrm{g}$ (weighed in air) of ethyl alcohol, for $20^{\circ} \mathrm{C}$. and constant pressure. Their calorimeter was calibrated with benzoic acid, using the value $6.333 \mathrm{~kg}$-cal.20 per $\mathrm{g}$ as its heat of combustion at constant volume. Substituting Dickinson's value (25) for benzoic acid gives 1,364 international kilojoules per mole at $25^{\circ} \mathrm{C}$. and a constant pressure of 1 atmosphere.

The details of the experiments by Roth and Müller (17) are unpublished. They give the value $7.140 \mathrm{~kg}^{-\mathrm{cal}} ._{15}$ for the heat of combustion of $1 \mathrm{~g}$ of ethyl alcohol (weighed in air) at $20^{\circ} \mathrm{C}$. and constant 


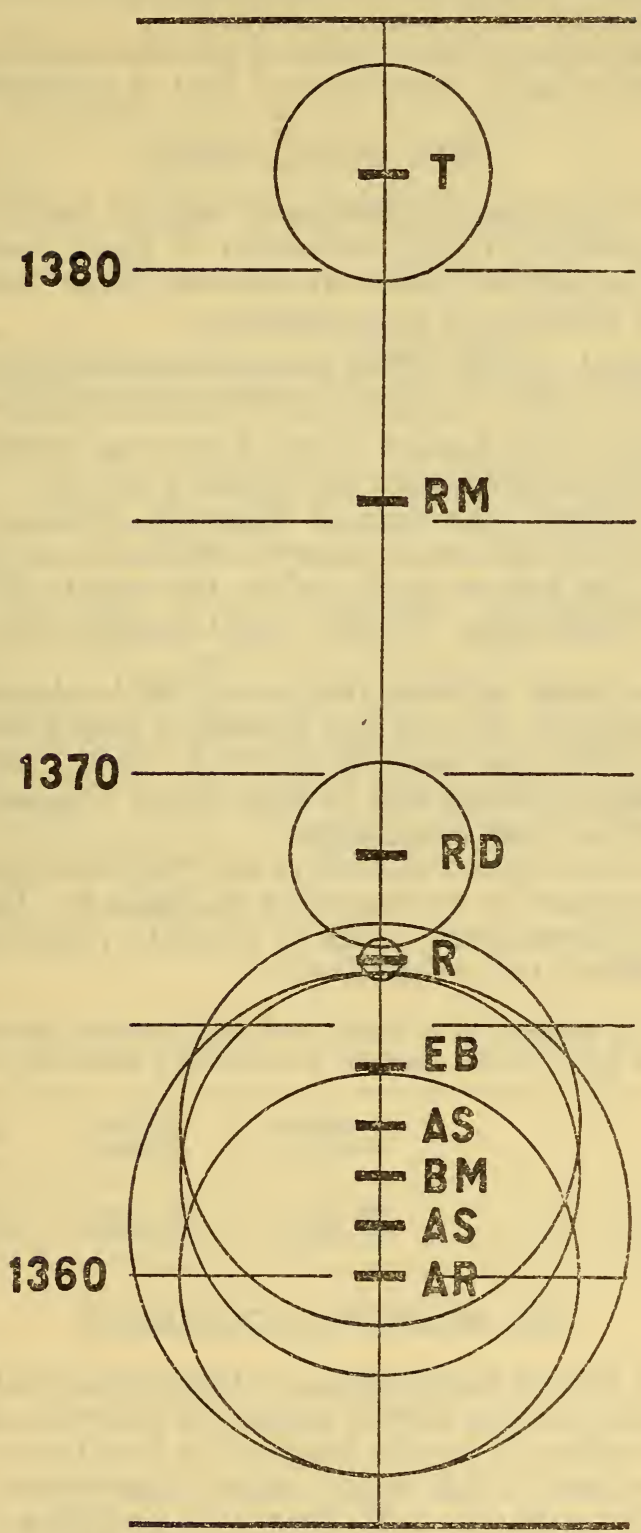

Figure 3.-Plot of the data on ethyl alcohol

The ordinate scale gives the heat of combustion of liquid ethyl alcohol at $25^{\circ} \mathrm{C}$. and a constant pressure of 1 atmosphere, in international kilojoules per mole. The circles measure the assigned "error" of the respective average values which are given for the following investigations: $A R$, Atwater and Rosa; $A S$, Atwater and Snell; $B M$,

Berthelot and Matignon; $E B$, Emery and Benedict; $R D$, Richards and Davis; $R M$, Roth and Müller; T', Thomsen; $R$, Rossini. 
volume. This gives, for $25^{\circ} \mathrm{C}$. and constant pressure, the value $1,375.4$ international kilojoules per mole.

In Figure 3 are plotted the results of the above-mentioned investigations on ethyl alcohol, together with that of the present work.

\section{CONCLUSION}

The data of the present experiments lead to the following values for the heats evolved in the combustion of liquid methyl and ethyl alcohols to form gaseous carbon dioxide and liquid water at $25^{\circ} \mathrm{C}$. and a constant pressure of 1 atmosphere:

Methyl alcohol: $726.25 \pm 0.20$ international kilojoules per mole

Ethyl alcohol: $1,366.31 \pm 0.40$ international kilojoules per mole

The relation of these data to those of previous investigators can be readily seen from an inspection of Figures 2 and 3.

For methyl alcohol, the data of Thomsen, Roth and Banse, and the I. G. Farbenfabrik, are in accord, within the assigned limits of "error," with the present work, while the results of Richards and Davis, and of Stohmann, Kleber, and Langbein are about 1.7 per cent lower.

In the case of ethyl alcohol, the data of Richards and Davis, Berthelot and Matignon, Emery and Benedict, and Atwater and Snell are in accord, within the assigned limits of "error," with the present data. The results of Roth and Müller and of Thomsen are, respectively, 0.67 and 1.14 per cent higher.

The heats of combustion of methyl and ethyl alcohols in the liquid state are summarized in various units in Table 9. The factors used for converting international joules to absolute joules and g-cal.15 are 1.0004 and $1.0004 / 4.185$, respectively.

TABLE 9.-Heats of combustion of methyl and ethyl alcohols (per mole of the liquid, at $25^{\circ} \mathrm{C}$. and a constant pressure of 1 atmosphere)

\begin{tabular}{|c|c|c|c|}
\hline & $\begin{array}{l}\text { International } \\
\text { kilojoules }\end{array}$ & $\begin{array}{l}\text { Absolute } \\
\text { kilojoules }\end{array}$ & Kg-cal.15 \\
\hline $\begin{array}{l}\mathrm{CH}_{3} \mathrm{OH}(l) \\
\mathrm{C}_{2} \mathrm{H}_{5} \mathrm{OH}(l) \ldots \\
\end{array}$ & $\begin{array}{r}726.25 \pm 0.20 \\
1366.31 \pm 0.40\end{array}$ & $\begin{array}{r}726.54 \pm 0.20 \\
1366.86 \pm 0.40\end{array}$ & $\begin{array}{l}173.61 \pm 0.05 \\
326.61 \pm 0.10\end{array}$ \\
\hline
\end{tabular}

\section{ACKNOWLEDGMENTS}

This work is part of the program of thermochemical research that is being carried on at this bureau under the direction of E. W. Washburn, and the author is greatly indebted to him for his deep interest in the problem and for his many valued suggestions. Grateful acknowledgment is made to J.H. Bruun for purifying the alcohols, to the gas chemistry section of this bureau for developing the flame technic and for making the carbon monoxide tests, and to the chemical reagents laboratory of this bureau for performing the test for nitric acid.

\section{BIBLIOGRA PHY}

1. Giauque, J. Am. Chem. Soc., vol 52, pp. 4808, 4816; 1930; vol. 53, p. 507; 1931.

2. Rossini, B. S. Jour. Research, vol. 6, pp. 1, 37; 1931.

3. Fiock, Ginnings, and Holton, B. S. Jour. Research, vol. 6, p. 881; 1931. 
4. Baxter, Curie, Hönigschmid, LeBeau, and Meyer. First Report of the Committee on Atomic Weights of the International Union of Chemistry, J. Am. Chem. Soc., vol. 53, p. 1627; 1931.

5. International Critical Tables, vol. 5, pp. 80, 81, McGraw-Hill Book Co., New York; 1929.

6. Bruun, Ind. Eng. Chem., anal. ed., vol. 1, p. 212; 1929.

7. International Critical Tables, vol. 3, p. 27, McGraw-Hill Book Co., New York; 1928.

8. Osborne, McKelvey, and Bearce, B. S., Bull., vol. 9, p. 327; 1913.

9. Woodman, "Food analysis," p. 496, McGraw-Hill Book Co., New York; 1924.

10. Lunge, "Technical Gas Analysis," p. 316, Van Nostrand Co., New York; 1914.

11. Rossini, Proc. Nat. Acad. Sci., vol. 17, p. 343; 1931.

12. Rossini, B. S. Jour. Research, vol. 7, p. 329; 1931.

13. Favre and Silbermann, Ann. chim. phys., vol. 34 , p. 357; 1852.

14. Thomsen, "Thermochemische Untersuchungen," vol. 4, pp. 157-159, Barth, Leipzig; 1886.

15. Stohmann, Kleber, and Langbein, J. prakt. Chem., vol. 40, p. 341; 1889.

16. Richards and Davis, J. Am. Chem. Soc., vol. 42, p. 1599; 1920.

17. Roth and Müller, unpublished. Quoted from Landolt-Börnstein-RothScheel Tabellen, first supplementary volume to the 5 th ed., p. 868, Springer, Berlin; 1927.

18. Roth and Banse, and I. G. Farbenfabrik, unpublished. Quoted from Landolt-Börnstein-Roth-Scheel Tabellen, second supplementary volume to the 5th ed., pt. 2, p. 1636, Springer, Berlin; 1931.

19. Richards and Jesse, J. Am. Chem. Soc., vol. 32, p. $268 ; 1910$.

20. Andrews, Phil. Mag., vol. 32, p. 321; 1848.

21. Berthelot and Matignon, Ann. chim. phys., vol. 27, p. 310; 1892.

22. Atwater and Rosa, Phys. Rev., vol. 9, p. 214; 1899.

23. Atwater and Snell, J. Am. Chem. Soc., vol. 25, p. 659; 1903.

24. Emery and Benedict, Amer. J. Physiology, vol. 28, p. 301; 1911.

25. Dickinson, B. S., Bull., vol. 11, p. 189; 1915.

Washington, November 18, 1931. 